\title{
Integrating Rich Task into the Mathematics Classroom to Develop Students' Higher Order Thinking Skills: A Collaborative Action Research Study in a Secondary School
}

Fitriati Fitriati, Teacher Professional Education Department of STKIP Bina Bangsa Getsempena, fitriati@bbg.ac.id, ORCID: 0000-0002-1238-2769

Marlaini Marlaini, Mathematics Teacher of Public Senior High School 4 Banda Aceh, marlaini.marlaini67@gmail.com, ORCID: 0000-0001-6046-9757

Elizar Elizar, Mathematics Education Department of Universitas Syiah Kuala, elizar@unsyiah.ac.id, ORCID: 0000-0001-8063-9450

\begin{abstract}
This paper reports a collaborative action research study about the use of rich tasks in a mathematics classroom. It aims at exploring how to implement rich mathematical tasks using the problem-based learning model. It also investigates student higher order thinking skills improvement toward the use of this instructional approach and the difficulties faced by the students. Twenty-one Year 9 students were involved in this study. The results of the study showed significant learning gains in three research cycles. After the teacher and researcher made some improvements, student higher order thinking skills became significantly higher in the second and third cycles. The improvement included providing learning sources, implementing Number Head Together (NHT) learning method, and adding more modelling activities in the student worksheet. Some recommendations related to teachers' preparations for rich task implementation in the classroom are presented based on teachers' and students' comments as well as existing literature.
\end{abstract}

Keywords: Rich Tasks, Problem based Learning, HOTS, Mathematics Instruction, CAR

Received: 20.05.2020 Accepted: 24.08.2020 Published: 01.12.2020

\section{INTRODUCTION}

Mathematics plays an important role in everyday life. It is one of knowledge fields that can contribute to the understanding of a situation. In today's mathematics classroom, it is experienced as a way of thinking, a way of communicating, and perceiving the world with significant links to all aspects of human experiences (Flewelling \& Higginson, 2002). These perceptions of mathematics demand to ensure that students have enough and proper training to live in modern and complex society (OECD, 2012; Gravemeijer, Stephan, Julie, Lin \& Ohtani, 2017). Many efforts have been made in setting more challenging goals in mathematics curriculum across countries around the world (Confrey, Gianopulos, McGowan, Shah, \& Belcher, 2017; Hadar \& Tirosh, 2019; Pak, Polikoff, Desimone \& Saldivar, 2020). For example, in the Australian and Finland curriculum, the instruction focuses more on promoting student thinking than remembering facts and routine procedures. While mathematics curriculum in Korea and Singapore retains the high level of mathematical competences as documented in TIMSS and PISA results such as critical thinking and problem-solving expertise (Udi, Clacke \& Kuntze, 2013).

Such change also occurs in Indonesia, where the Indonesian Government decides to employ the new 2013 curriculum which is expected to give students a learning experience that can develop their higher order thinking skills (HOTS). This curriculum was developed based on the comprehensive evaluations of TIMSS and PISA results, which revealed that Indonesian students' mathematics literacy had not shown pleasing reality: it is consistently under the average of the international standard score (Pratiwi, 2019; OECD, 2018; Hadi, Retnawati, Munadi, Apino \& Wulandari, 2018; Stacey, 2012). It indicates that the current Indonesian mathematics curriculum has not successfully taught the skills needed by the students. Therefore, the new 2013 mathematics curriculum and assessment focus on a range of 21st-century skills that aims to 
develop students' higher order thinking skills (HOTS), such as critical thinking and problemsolving, to prepare them to live in a complex and ever-changing world.

HOTS was introduced in the Indonesian Mathematics Curriculum in 2016, and it is defined as the cognitive skills of analyzing, evaluating and creating levels based on the revised Bloom's Taxonomy. It is also seen as thinking skills that require students to transfer one concept to another, process and use the information, find connections among various different information, apply the information given to solve the problem, and critically explore ideas and information (Ministry of Education and Culture, 2018). HOTS is playing a vital role in enhancing students thinking skills that are urgent and relevant to current global needs and challenges (Alpino \& Retnawati, 2017; Hadi et al. 2018). The benefits of HOTS are seen through the rich experience where students used a complex thinking process in applying knowledge, drawing a conclusion, developing a representation, analyzing, and developing a relationship that involves basic mental activity (Ministry of Education and Culture, 2018). In short, instruction based on HOTS serves to develop skills, such as transferring, problem-solving and critical thinking (Brookhart, 2010). Therefore, such instruction should be incepted in the daily mathematics classroom to achieve the learning outcomes expected by the Government.

As the elevation of HOTS has become a priority in the daily mathematics classroom, there is limited specific advice on how this can best happen. Even though the new curriculum requires the teachers to employ constructivist teaching and learning strategies to develop the HOTS of the students, such as project-based learning, problem-based learning, contextual learning and collaborative-based learning (Ministry of Education and Culture, 2018), the teaching practices implemented by teachers merely focused on traditional teaching methods (Tanujaya, Prahmana, \& Mumu, 2017). Some previous studies conducted on mathematics instruction by local researchers (Husamah, Fatmawati \& Setyawan, 2018; Alpino \& Retnawati, 2017; Jailani \& Retnawati, 2016; Jaelani, Sugiman \& Alpino, 2017) serve to promote HOTS among secondary and university students. Researchers carried most of these studies without involving teachers directly. There are also fewer local studies on the development of students HOTS, which collaborates with mathematics teachers.

In addition, based on observation conducted by researchers under 'the lecturer goes to school program in 2019" in one of the public junior high schools in Banda Aceh, it is found that teachers still mainly use routine mathematical activities or tests which less emphasize on HOTS. Through a Focus Group Discussion (FGD), mathematics teachers and the school principal revealed that conducting HOTS based instruction in the daily mathematics classroom is challenging for most teachers. Their knowledge and skills related to HOTS were still limited. Teachers also reported that the students' interest and motivation in learning mathematics were quite low, making it difficult for the teacher to implement HOTS. This low interest and motivation, even, make teaching basic mathematics concepts become a difficult task for teachers. These findings are relevant to several previous studies conducted by Retnawati et al. (2017), Jaelani and Retnawati (2016), Nurlaily, Soegiyanto and Usodo (2019) who found the barriers encountered by teachers in implementing the problem-based learning for improving HOTS in a daily mathematics classroom. These comprised difficulties in planning the lesson (making the learning plan and determining the problems) and implementing them (engaging students in the learning process). This indicates that further research concerning teaching HOTS among secondary school students is necessary.

The rich task is one solution that could be used to stimulate HOTS (Moulds, 2002; Ferguson, 2009; Henningsen \& Stein, 1997; Slavit \& Nelson, 2010; Goos et al. 2013; Glover, 2016; Foster, 2017; Fitriati \& Novita, 2018). A rich task is an assessment tool that is considered a valuable component of teacher practices (Grootenboer, 2009; Aubusson, Burke, Schuck, Kearney \& Frischknecht, 2014). There have been several studies in the literature reporting the concept of rich tasks (Grootenboer, 2009; Goos, Geiger \& Doley, 2013; Aubusson et al., 2014; Glover 2016; Foster 2017). The most comprehensive definition of rich tasks was proposed by DarlingHarmond (2012:302) in her paper. 
A culminating performance or demonstration or product is purposeful and models a life role. It presents substantive, real problems to solve and engages learners in forms of pragmatics social action that have real value in the world. The problems required identification, analysis, and resolution and require students to analyze, theorize and engage intellectually with the world. As well as having this connectedness to the world beyond the classroom, the task also rich in their application, they represent the educational outcome of demonstrable and substantial intellectual and educational value.

Rich tasks have been implemented across school subjects, including in mathematics, as known as rich mathematical tasks (Lingard et al. 2001). Piggott (2012) defined a rich mathematical task as a task that could engage learner's interests from the start, allow further challenges, invite learners to make decisions, involve the learner in speculating, hypothesis making and testing, proving and explaining, reflecting and interpreting as well as could promote discussion and communication and encourage originality and invention. This description proposed by Piggott incorporated those used by others, such as Henningsen and Stein (1997), Moulds (2002), who also explained that students were engaged in the learning process utilizing rich tasks. Through rich tasks, they understand the contents meaningfully, foster connections among ideas and disciplines as well as provide students the opportunity to apply their mathematics knowledge to solve real-world problems that require HOTS and comprehensive understanding.

Regarding the issue and the rich task's potential above, the researchers and teachers agreed to work collaboratively to develop and conduct innovative instruction to enhance students' HOTS. To accomplish this aim and to respond to a recent call for research, this study sets rich tasks through a problem-based learning model in mathematics classrooms as students' learning activities. The students' development of HOTS, especially problem solving, is investigated. This paper analyzes how problem-based learning with the rich task used to develop students' HOTS by reflecting on the teacher teaching process, identifying students' difficulties in solving the rich task, and providing support for them. The students' HOTS improvement in each learning cycle was also measured. This study is potentially significant in providing information about rich tasks and its potentials in developing HOTS of the students which might be accommodating in teacher professional development program. It is expected that teachers will have valuable insights into improving students' HOTS by applying rich tasks extensively in daily their teaching practice.

\section{METHODS}

This present study was conducted as part of the "lecturer goes to school program" funded by the Ministry of Research and Higher Education of Republic Indonesia in 2019. One of the purposes of this program is that lecturers and teachers develop innovative teaching models collaboratively, which might be used in the daily teaching process to improve instructional quality and student achievement in Indonesia. In line with this objective, therefore, this study employed collaborative action research (CAR) that used to enhance students HOTS. This research design was used as it "is characterized by its focus on practical problems of individual teachers or schools and its emphasis on professional development and support for collaboration between teachers and university staff" (Raymond \& Leinenbach, 2000; p.285). It also provides a medium for university researchers and classroom teachers to systematically examine the problems they face in their classrooms to find practical solutions and enhance their understanding of the intervention measures that are needed (Creswell, 2009) and helps researchers to explore the nature of their practice and to improve it (Doğan \& Cilic, 2020). HOTS was measured during the learning processes utilizing a problem-based learning model with rich tasks in a cyclic process. This research was referred to as the spiral model of Kemmis, McTaggart and Nixon (2014), consisted of four important stages, i.e., (1) planning, (2) action, (3) observation and (4) reflection.

This study consisted of three action research cycles, with two meetings for each cycle $5 \mathrm{x}$ 40 minutes). Each cycle research comprises four main stages: planning, acting, observing and 
reflecting. In the planning stage, the researchers and teachers work collaboratively to design instruction tools based on the problem-based learning model. The tools were lesson plan, student worksheet of rich tasks and other required research instruments (schedule, pre-cycle test, observation sheet and interview protocol). The action phases were the implementation of the planning phase, where the activities conducted as planned in the first phase, including the observation process, which also done during this phase. At the end of the learning process, the reflection phase was conducted to evaluate the strengths and weaknesses of learning treatments as well as the difficulties students experienced in managing rich tasks. The plan was revised after each cycle in the light of the experiences gained through observation and reflection. Based on the results of this reflection, then it was decided to continue and terminate the cycle.

\section{Participants}

All students $(\mathrm{N}=21)$ from one Year 9 classrooms of a public junior high school in Banda Aceh, Indonesia, and their teachers, including the researchers, participated in this study. The teachers and students were selected based on the principal's recommendation. We planned for teaching one topic in this study, i.e., "quadratics equation". We prepared all the teaching materials needed, such as rich tasks as a test instrument and mathematics activity, student worksheet, PowerPoint slides for content notes, journal reflection format and interview protocol.

\section{The Instruments}

This study employed four primary data sources: tests, student worksheets, teacher reflection, and student's interview. This study used qualitative data collection methods, including the teacher reflective journal and interview protocol, to collect data about how problem-based learning with rich tasks helps the teacher develop HOTS. To examine the increasing of students HOTS before and after the learning cycle, tests and student worksheets concerning rich tasks were administered. Student worksheets had been developed in a previous study (Fitriati \& Novita, 2018). All rich tasks administered in the test and student worksheet were adopted and modified from NRICH Website (2019), so they have robust validity and reliability. We select four rich mathematical tasks related to the quadratic equation topic, which suit Indonesia's mathematics secondary school curriculum. These selected tasks were translated and assessed by the researchers using rich task characteristics developed by the NRICH Team to ensure the richness of the tasks.

The study also conducted student interviews to get insight into their thinking while solving the given rich tasks. The semi-structured interview was based on how the students solved rich tasks to understand students' perception of rich task-based instruction. Interview questions focus on two major aspects: (a) the challenges or difficulties in solving rich tasks and b) suggestions for improvement. As a problem-based learning model requires students to work in a group, groups of students were interviewed for 15 minutes at the end of the learning process. Besides, all learning activities during each research cycle were video recorded.

\section{Design of the Teaching Intervention}

Mathematics instruction for the quadratics equation topic was delivered through problem-based learning with rich tasks. All learning materials were designed collaboratively by the researchers and teacher. This was conducted as the researchers took into account the previous finding Jaelani and Retnawati (2016); Jaelani, Sugiman and Alpino (2017); Alhassoram Abu and Abdullah (2017), who reported that teachers' unpreparedness was one of the obstacles encountered within the implementation of PBL model. In the implementing phase of the first cycle, the teacher explained what the lesson is about, what are the teacher's expectations from the lesson (such as solving rich tasks to explore their mathematical modelling and problemsolving ability) and what are the activities for students to do at the beginning of PBL approach. This conducted to scaffold student learning so that the expected outcomes might appear. Table 1 provides a brief description of the learning activities conducted using five steps of problem-based learning and rich tasks to develop students HOTS. 
Table 1. Learning activities following problem based learning model with rich tasks

\begin{tabular}{|c|c|c|}
\hline $\begin{array}{l}\text { Problem based Learning } \\
\text { Model with Rich tasks }\end{array}$ & Learning activities & Expected Learning Outcome \\
\hline $\begin{array}{l}\text { Phase 1: Orienting student to } \\
\text { problems }\end{array}$ & $\begin{array}{l}\text { - Students are reminded about } \\
\text { the previous lesson topic and } \\
\text { are motivated by trying to } \\
\text { understand the learning } \\
\text { objectives, taking into account } \\
\text { the direction of the learning } \\
\text { process and the skill of } \\
\text { problem-solving presented by } \\
\text { teachers } \\
\text { - Students are exposed to the rich } \\
\text { task which shown on the } \\
\text { projector screen and student } \\
\text { worksheet }\end{array}$ & $\begin{array}{l}\text { - Understanding the rich task by } \\
\text { exploring the situation before } \\
\text { pinning things down }\end{array}$ \\
\hline $\begin{array}{l}\text { Phase 2: Organizing student to } \\
\text { learn }\end{array}$ & $\begin{array}{l}\text { - Students gather in the } \\
\text { heterogeneous group }(4-5 \\
\text { students) to solve mathematical } \\
\text { problems (rich tasks) } \\
\text { administered through the } \\
\text { student worksheet. } \\
\text { - Students work collaboratively } \\
\text { to solve the given rich tasks. }\end{array}$ & $\begin{array}{l}\text { - Working in a group and } \\
\text { understanding their roles in a } \\
\text { group } \\
\text { - Solving the rich task } \\
\text { collaboratively through think- } \\
\text { pair-share }\end{array}$ \\
\hline $\begin{array}{l}\text { Phase 3: Guiding individual or } \\
\text { group investigation }\end{array}$ & $\begin{array}{l}\text { Teachers guide students in solving } \\
\text { rich tasks. In guiding the students, } \\
\text { the teacher conducts the following } \\
\text { activities: } \\
\text { - The teacher posed students } \\
\text { with several questions related } \\
\text { to problem-solving: (1) What } \\
\text { is the objective required? (2) } \\
\text { How reasonable is the } \\
\text { solution? } \\
\text { The teacher asked students to } \\
\text { think reflectively by } \\
\text { questioning them as follows: } \\
\text { (1) how do you think you are } \\
\text { correct? And (2) have you } \\
\text { found all the possibilities? }\end{array}$ & $\begin{array}{l}\text { - Posing as well as solving } \\
\text { problems, making conjectures } \\
\text { - Considering and sharing } \\
\text { different ways of representing } \\
\text { the information } \\
\text { - discussing different ways of } \\
\text { tackling a problem. }\end{array}$ \\
\hline $\begin{array}{l}\text { Phase 4: Developing and } \\
\text { presenting the results }\end{array}$ & $\begin{array}{l}\text { Students prepare their responses } \\
\text { to be presented in front of the } \\
\text { class and let their peers to } \\
\text { question or to give suggestions }\end{array}$ & 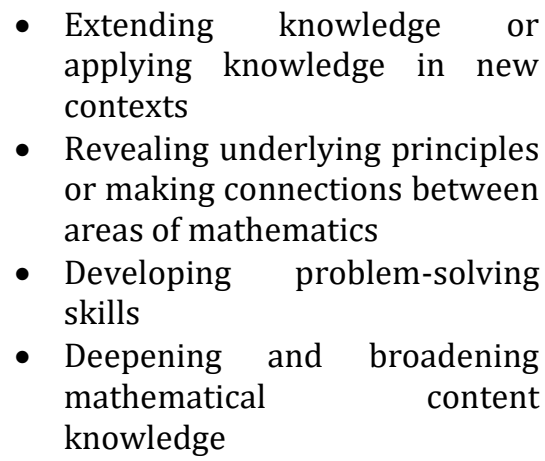 \\
\hline $\begin{array}{l}\text { Phase 5: Analyzing } \\
\text { evaluating process }\end{array}$ & $\begin{array}{l}\text { - Students evaluate the processes } \\
\text { and their solution to the rich } \\
\text { task } \\
\text { - Teachers provide follow-up } \\
\text { tasks for individual students to } \\
\text { be solved outside of the school } \\
\text { hours as an exercise }\end{array}$ & $\begin{array}{l}\text { Evaluating their peer response } \\
\text { critically through reasoning }\end{array}$ \\
\hline
\end{tabular}


This learning activity was implemented in each cycle. In the first cycle, the researcher (lecturer) acted as a teacher to show the teacher how to conduct a problem-based learning model with rich tasks while the teacher observed the learning process conducted by the researcher. Based on this observation data, the teacher and the researcher wrote a reflective journal. This activity was done as the researcher anticipated that the teacher had a lack of teaching experience related to rich tasks. Having observed the learning process in this cycle, the teacher taught the next two cycles, and the researcher acted as the observer. The researcher also wrote a reflective journal.

\section{Scoring}

This study measures problem-solving skills as HOTS (Brookhart, 2010). The students' responses on a rich task were scored ranging from 0 to 100 based on the problem-solving indicators proposed by Polya (1973): (a) understand the problem; (b) devise a plan; (c) carry out the plan; and (d) look back. A full correct answer for each rich task item corresponds to the ability of (a) identifying information that are known and unknown, what is being asked and which mathematical knowledge needed to solve a problem; (b) formulating a mathematical problem or compiling a mathematical model; (c) applying strategies to solve problems or mathematical models and (d) explaining or interpreting the result according to the original problem and using mathematics meaningfully (Tambunan, 2019). The HOTS scores were classified into three categories: 0-60 (low), 61-80 (fair) and 81-100 (very good) (Husamah et al. 2018).

\section{Data Analysis}

As classroom action research uses both qualitative and quantitative data (Creswell, 2009), the data of this study were analyzed qualitatively and quantitatively. A qualitative approach was used to analyze the data from the reflection Journal (written by the teachers and researchers) and the interview data. These data were analyzed using a series of qualitative procedures consisting of transcribing process, analyzing thematically and organizing into categories (Corbin \& Strauss, 2008). The data were then translated into English for reporting purposes. While, the data on student responses concerning the given rich tasks, both in the tests and student worksheet were analyzed quantitatively. These data were inputted into an Excel spreadsheet and later imported into SPSS for analysis. The percentage formula was used to measure the students' HOTS improvement throughout the learning process. This study also conducted repeated measures ANOVA method (Field, 2009) to determine any significant improvement of students' HOTS in each cycle.

\section{RESULTS}

\section{Overview of the three action research cycles}

The study was conducted in three cycles, following the four stages: planning, acting, observing and reflecting. Table 2 illustrates the research process adapted from Kwan (2014). Based on the data collected during the action and observation phase throughout research cycles, it shows that the learning activities expected from utilizing rich tasks in mathematics instruction occurred. The learning process conducted during this study provided students opportunity to solve real-world problems by working collaboratively in group, extending knowledge or applying it in the new contexts, revealing underlying principles or making connections between areas of mathematics, considering and sharing different ways of representing the information, discussing different ways of solving a problem and evaluating their peer responses critically through reasoning. When these activities appeared in the learning process, the development of students HOTS is expected. This is in line with King, Goodson and Rohani (2011) who argued that successful application of HOTS results in explanation, decision, performances and products that valid within the context of knowledge and experience. Besides, the obstacles faced by students during the implementation of rich tasks were also prevalent. 
Table 2. The Overview of the research process

\begin{tabular}{|c|c|c|}
\hline Phase & Action research stage & Major tasks \\
\hline $\begin{array}{l}\text { Phase 1: } \\
\text { Pre-cycle }\end{array}$ & $\begin{array}{l}\text { Reviewing the current } \\
\text { practice, identify problems } \\
\text { and pre-cycle test of students } \\
\text { HOTS ability } \\
\text { - Planning }\end{array}$ & $\begin{array}{l}\text { - Conducting FGD with teachers and } \\
\text { school principal and pre-cycle test } \\
\text { to students } \\
\text { - Discussing and designing the action } \\
\text { plan with the teacher } \\
\text { - Preparing teaching materials (rich } \\
\text { task, lesson plan, student } \\
\text { worksheet and PowerPoint slides) } \\
\text { - Developed other research } \\
\text { instruments (student interview } \\
\text { protocol and teachers reflection } \\
\text { protocol) }\end{array}$ \\
\hline $\begin{array}{l}\text { Phase 2: } \\
\text { Intervention } \\
\text { First Cycle }\end{array}$ & Acting and Observing & $\begin{array}{l}\text { - Implementing the problem-based } \\
\text { learning model with rich task } \\
\text { - Peer Observation of Teaching } \\
\text { - Teacher reflection }\end{array}$ \\
\hline $\begin{array}{l}\text { Second Cycle } \\
\text { and Third Cycle }\end{array}$ & $\begin{array}{l}\text { Reflecting, re-planning and re- } \\
\text { acting }\end{array}$ & $\begin{array}{l}\text { - Analyzing data of the previous cycle } \\
\text { - Refining and re-implementing } \\
\text { problem based learning with rich } \\
\text { tasks } \\
\text { - Data analysis } \\
\text { - Writing up the final report }\end{array}$ \\
\hline
\end{tabular}

Through the reflective journal, the teacher noted some problems in the learning process. In the first cycle of rich task intervention, it is found that students encountered some difficulties in solving the rich tasks, including: (1) transformation difficulty, (2) process skill difficulty and (3) encoding difficulty. These difficulties also can be seen in their works (rich task responses). Students' first difficulty was transformation difficulty, which indicated by students' inability to develop a mathematical model to represent the information/statement of the given rich task. This type of difficulty can also be seen from students' errors in selecting the formula to use and complete the rich task. Figure 1 illustrates these findings.

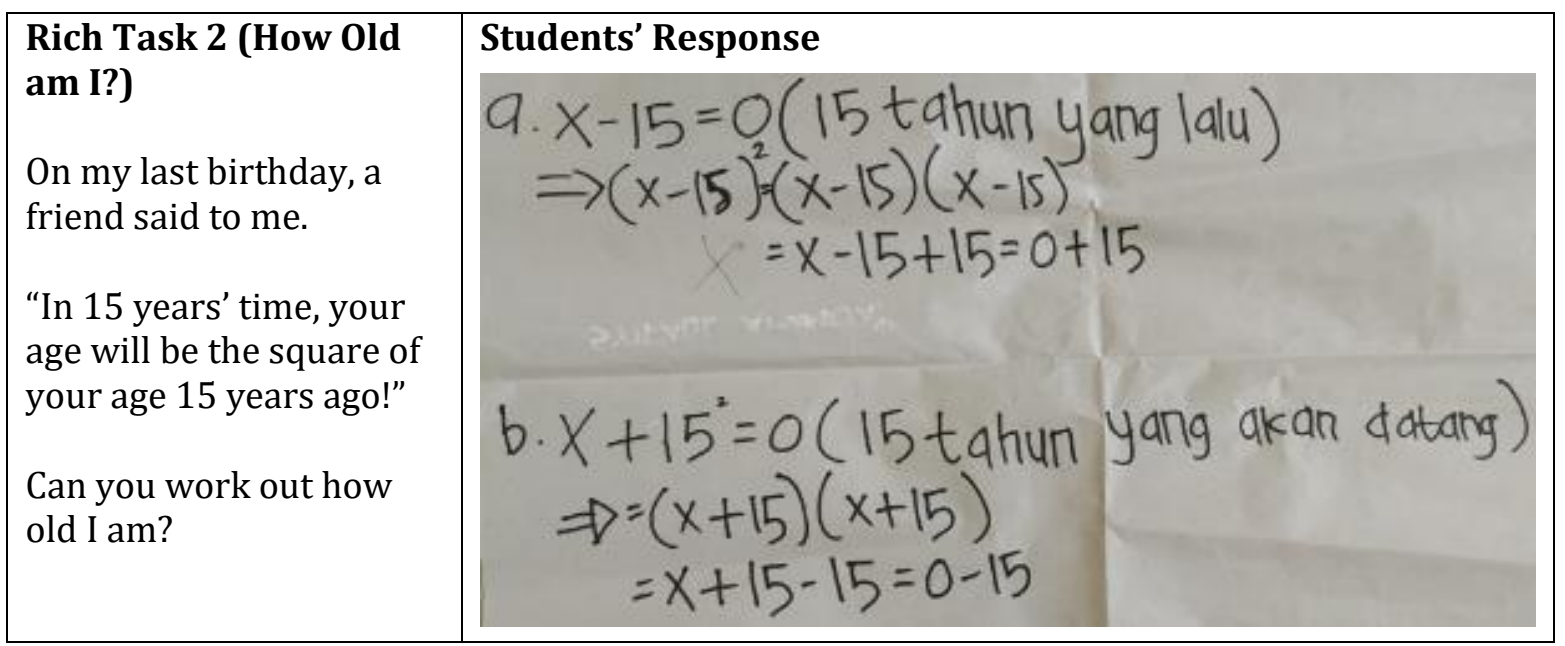

FIGURE 1: Example of the Student's Transformation Difficulty 
This difficulty was also found while teacher observed students writing their solution. The teacher noticed that students struggled to connect the abstract aspects to reality, which resulted in incorrectly applying the strategy. It was also found that as students cannot develop the mathematical model of the problem, they cannot completely solve the rich tasks. This information was confirmed in the student interview when the teacher questioned them why their responses were unfinished. Students answered, "I don't know how to create a mathematical model of that situation, but when you (teacher) gave a clue or direction, then I could develop one. Before that, I felt this rich task was so difficult, but when a mathematical model was made, it was actually easy, I know which mathematical procedures to use to solve this task". It can be concluded that students' ability to solve the problem depends on their ability to model the given situation mathematically.

Another student's difficulty found was related to a process skill. It was evident when students showed computational weakness, such as students' error in implementing formula, in math calculation and in algebraic manipulation. Figure 2 provides an example of this difficulty in student work.

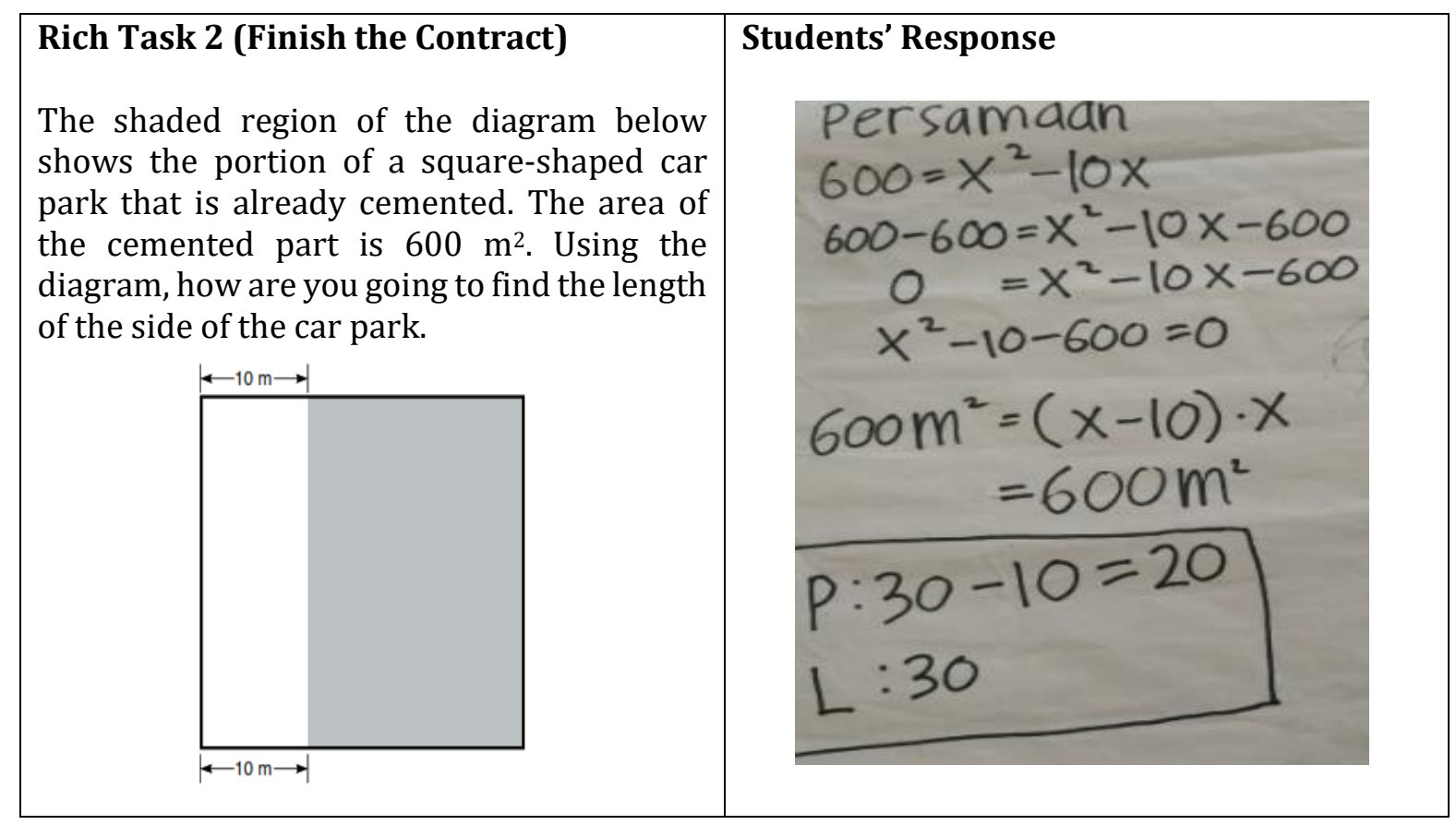

FIGURE 2: Example of the Student's Process Skill Difficulty

Students' response indicates that students were inconsistent at computing. From the interview, the teacher found that this happened because students could not recall basic facts. They also could not solve the given rich tasks because they forgot about the mathematical principles or concepts needed (taught in Grade 7 and 8). The teacher's journal reflected how students ignored the context of the whole problem when they highlighted the rich tasks. Students did not use the strategy carefully and called for teachers to help to reinforce the key concepts of tasks.

The final difficulty is encoding difficulties, which are marked by students' errors in concluding. Students' responses on a rich task show that some of them failed to provide reasoning in justifying the conclusion. Figure 3 illustrates the student's difficulty.

From the interview, it was found that those difficulties experienced by the students because they were not familiar with the rich tasks. Both the teacher and students had no experience concerning learning by solving rich tasks. They used to apply the problem-based learning model many times, but the problem given were not rich tasks. One of the students said that "I never got a mathematical task like that, it is too difficult, I don't know what to do. My teacher used to give 
us routine problems; we can solve it directly". This fact was also confirmed in teacher's journal where the teacher wrote "Rich tasks is new for me and my students, I am so nervous and not confident teaching with rich tasks, even I don't know the solution of the given rich tasks, but the lecturer guide me so well, with her help finally we conducted the instruction as planned before."

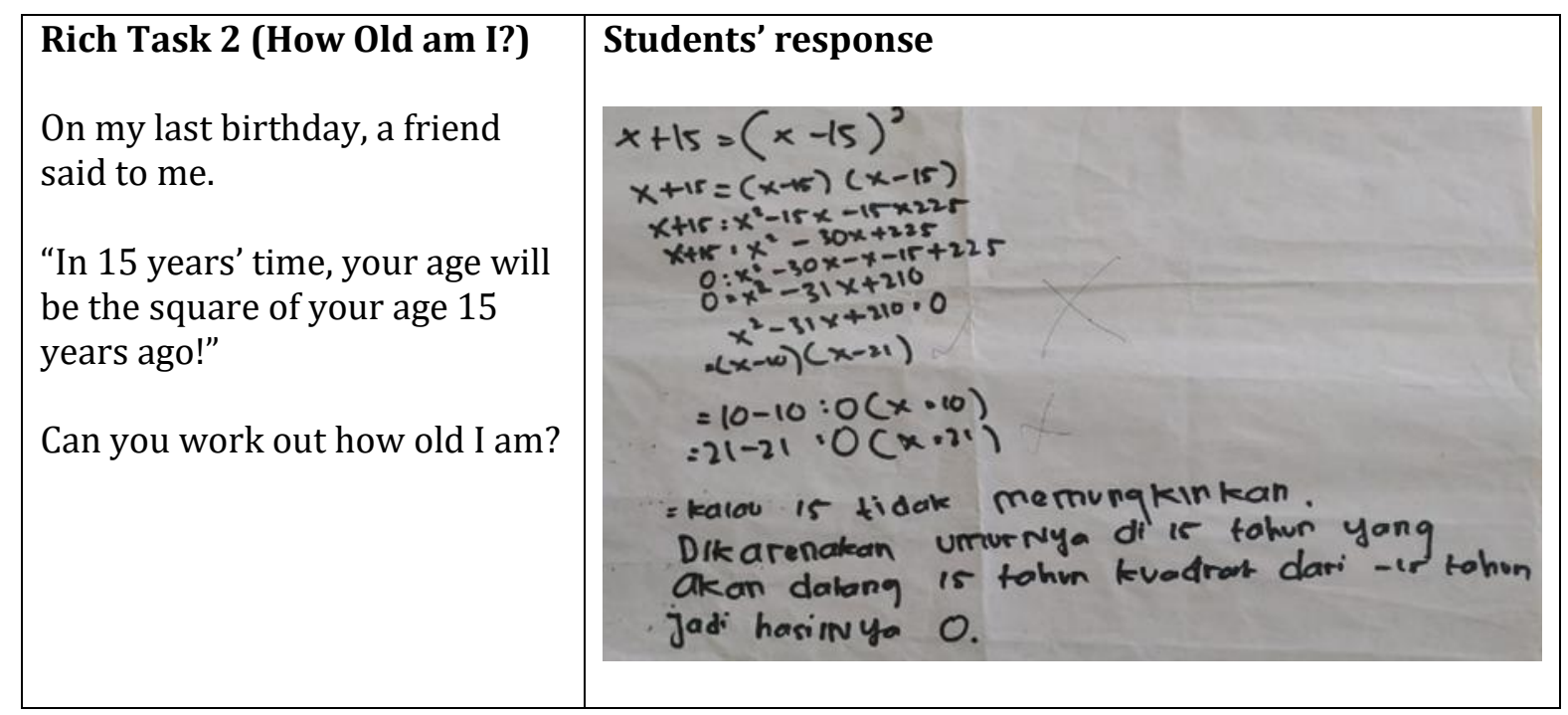

\section{FIGURE 3: Example of the Student's Encoding Difficulty}

This condition is beyond the government expectation, what happens in the classroom totally differs from the ideal condition expected. The Government, through the 2013 curriculum, has mandated the teacher to use HOTS related mathematics task/activity during the learning process, applying a problem-based learning model, discovery learning model and project-based learning model. Therefore, secondary school students must be trained toward HOTS by giving rich tasks following PBL approach during mathematics instruction. It is hoped that students will be more familiar with the tasks which ultimately improve their HOTS skills in the future.

Besides those barriers, the teacher also found that some students were not engaged in group discussions or fully participated during the learning process in the first cycle because they tended to confuse in generating the key idea in solving the given rich tasks. In the teacher's reflective journal, it is written that "some of the students in each group did not participate, they only stared at the student worksheet, and they seemed not to know what to do. I need to use another strategy to engage them in the learning process". This condition consumed more time than allocated. Some methods were introduced in the second and third cycles to overcome these problems, resulting in improving students HOTS and increasing students' engagement and interest in the learning process. Table 3 shows a detailed description of the solution offered in the next two cycles.

\section{Higher order thinking skills improvement}

Brookhart (2010) has defined HOTS as transfer, critical thinking and problem-solving. They are activated when students encounter complex and unfamiliar problems, questions, uncertainties, or dilemmas (King et al. 2011). These definitions refer to individual skills in solving complex problems with uncertainties. The research that was conducted from pre-cycle to the third cycle provides evidence that students' HOTS was demonstrated in the learning process when rich tasks were integrated into mathematics classrooms following the problem-based learning model. The results also show the improvement of the students' HOTS in each cycle. Table 4 shows that the students' HOTS scores exhibited a rising trend from pre-cycle to the third cycle. 
Table 3. Summary of teaching action proposed

\begin{tabular}{|c|c|c|}
\hline Problem & Solution & Activity \\
\hline $\begin{array}{l}\text { Difficulty in transferring real- } \\
\text { world condition into the } \\
\text { mathematical model }\end{array}$ & $\begin{array}{l}\text { 1. Encouraging students to } \\
\text { highlight keywords and to } \\
\text { illustrate the condition } \\
\text { using } \\
\text { picture/mathematics } \\
\text { symbols } \\
\text { 2. Providing more activities } \\
\text { related to the modelling } \\
\text { task in the student } \\
\text { worksheet. }\end{array}$ & $\begin{array}{l}\text { 1. Revising student } \\
\text { worksheet } \\
\text { 2. Re-planning the lesson } \\
\text { plan }\end{array}$ \\
\hline Difficulty in the process skill & $\begin{array}{l}\text { 1. Providing learning } \\
\text { sources, such as } \\
\text { textbooks, PowerPoint } \\
\text { presentation/handouts } \\
\text { and teacher guide or } \\
\text { explanation. } \\
\text { 2. Directing students to } \\
\text { utilize textbooks and } \\
\text { previous mathematics } \\
\text { lesson notes as a source of } \\
\text { learning to help them } \\
\text { recall prior learning } \\
\text { materials, skills and } \\
\text { strategies used. } \\
\text { 3. Providing math activities } \\
\text { related to the process skill } \\
\text { in the student worksheet } \\
\text { as the student exercise }\end{array}$ & $\begin{array}{l}\text { 1. Revising the student } \\
\text { worksheet (planning } \\
\text { phase). } \\
\text { 2. Designing learning sources, } \\
\text { such as textbooks, } \\
\text { presentation } \\
\text { slide/handouts. } \\
\text { 3. During the acting phase } \\
\text { teacher do the following } \\
\text { activities: } \\
\text { - Providing textbooks } \\
\text { - Presenting } \\
\text { PowerPoint slides/ } \\
\text { handouts to students } \\
\text { - Posing questions to } \\
\text { provoke students' } \\
\text { thinking following } \\
\text { rich task } \\
\text { characteristics }\end{array}$ \\
\hline $\begin{array}{l}\text { Difficulty in the encoding } \\
\text { (failed in defining the } \\
\text { conclusion) }\end{array}$ & $\begin{array}{l}\text { In order to help the student to } \\
\text { check their work, students } \\
\text { were required to: } \\
\text { 1. Read their answer to the } \\
\text { teacher, explain how they } \\
\text { derive at their findings } \\
\text { and relate them to the } \\
\text { main question } \\
\text { 2. to write down their } \\
\text { problems }\end{array}$ & $\begin{array}{l}\text { During the acting phase, } \\
\text { posing some questions to } \\
\text { students to provoke their } \\
\text { reasoning and critical } \\
\text { thinking }\end{array}$ \\
\hline $\begin{array}{l}\text { Not engaged and involved in } \\
\text { the learning process }\end{array}$ & $\begin{array}{l}\text { Applying Number Head } \\
\text { Together (NHT) learning } \\
\text { method where each student } \\
\text { was assigned to a number, } \\
\text { then the number was selected } \\
\text { randomly to present their } \\
\text { group work }\end{array}$ & $\begin{array}{l}\text { Revising lesson plan and } \\
\text { conducting the instruction } \\
\text { as designed in the lesson } \\
\text { plan. }\end{array}$ \\
\hline
\end{tabular}

These cyclic activities resulted in the improvement of student HOTS as describe in the following section. 
Table 4. The Trend of students' HOTS scores

\begin{tabular}{llllll}
\hline \multirow{2}{*}{ Activities } & \multicolumn{3}{c}{ HOTS Scores Categories } & Mean & N \\
\cline { 2 - 5 } & Low (0-60) & Fair (61-80) & Very Good (81-100) & & \\
\hline Pre-Cycle & 100 & 0 & 0 & 2.62 & 21 \\
Cycle 1 & 57.14 & 19.05 & 19.05 & 62.14 & 21 \\
Cycle 2 & 38.10 & 19.05 & 42.86 & 69.30 & 21 \\
Cycle 3 & 19.05 & 0 & 80.95 & 77.86 & 21 \\
\hline
\end{tabular}

Table 4 shows that all students (100\%) had a low HOTS score in the pre-intervention phase, indicating that all students failed in solving the rich tasks. However, the number of students with low HOTS category decreased in the next cycle following the intervention, reaching $57.14 \%$, $38.10 \%$ and $19.05 \%$. In contrast, the upward trend was shown in the fair and the very good categories, especially in the very good category. The mean scores of students' HOTS in each cycle were also improved. Figure 4 displays this increasing trend, which exhibited HOTS improvements among the students.

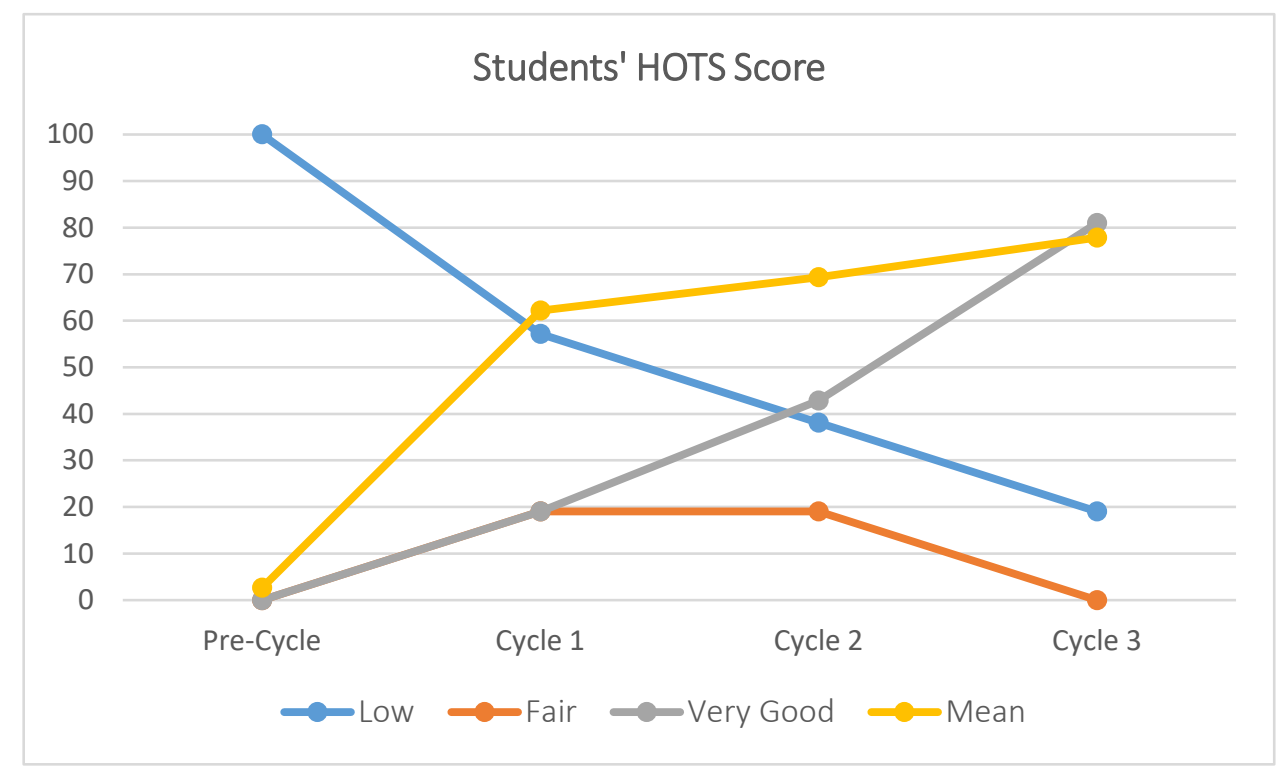

FIGURE 4. The Percentage of Students' HOTS Score Improvement per Cycle

The significance of the above percentage rising trends were also supported by statistical analysis (a one-way repeated-measure ANOVA). It was run to compare the effects of the four cycles of rich task-based instruction on students' HOTS in pre-cycle, cycle 1, cycle 2 and cycle 3. The results of the data analysis are provided in Table 5.

Table 5. Summary of a one-way repeated-measure ANOVA test

\begin{tabular}{lcccc}
\hline Rich Task Test & N & Mean & SD & Post hoc Bonferroni \\
\hline 1.Pre-Cycle & 21 & 2.62 & 7.04 & \\
2. Cycle 1 & 21 & 62.14 & 20.19 & $2>1^{* * * *}$ \\
3. Cycle 2 & 21 & 69.30 & 21.53 & $3>1^{* * * *}$ \\
4. Cycle 3 & 21 & 77.86 & 20.39 & $4>1^{* * * *}$ \\
${ }^{* * * *} \mathrm{p}<.0001$ & & &
\end{tabular}

Students learned mathematics with rich tasks following a problem-based learning model for three cycles. The normality test was carried out on the residuals and it was reported that the data is normally distributed. A repeated-measures ANOVA with a Greenhouse-Geiser correction showed that the mean of HOTS score differed significantly between cycles ( $F(1.885$, 
37.998) $=79.51, \mathrm{p}<0.001)$. Post hoc tests using Bonferroni correction revealed that students' HOTS improved by an average of 59.52 points after a problem-based instruction model with rich tasks used in the first cycle $(\mathrm{p}<0.001)$. It was improved by an additional 66.68 points between cycle 1 and $3(\mathrm{p}<0.001)$; and 75.24 points between cycle 1 and $4(\mathrm{p}<0.001)$. These indicated a learning gain after the intervention. The mean of HOTS score was not significantly different between cycle 1, 2 and 3, although it was an improvement in each cycle. This finding is reasonable since rich tasks used to measure the HOTS is challenging. These results suggested that problembased learning with the rich task was significantly improved students' HOTS.

\section{DISCUSSION AND CONCLUSIONS}

This collaborative action research aims to promote student HOTS using rich tasks delivered through a problem-based learning model. The integration of rich tasks was conducted through four action research phases completed in three cycles. The learning process utilizing rich tasks following PBL model allows students to solve real-life problems by investigating the situation, collaborating in a group, identifying various representation methods, linking mathematical concepts, fostering problem-solving skills, advancing subject matter knowledge and critical peerreview through reasoning. Besides, incorporating rich mathematical tasks enable students to apply their mathematical knowledge and skills and develop the complex reasoning process of problem-solving (Ferguson, 2009, Margolinas, 2013, Piggott 2012). These findings indicate that rich tasks could be used as a pedagogical approach in daily mathematics instruction to develop student HOTS.

Results of data analysis show that the most common difficulties encountered by students in solving rich tasks were transformation, process skill and encoding (Abu \& Abdullah, 2017; Hadi et al. 2018). It is found that students were struggled in transferring real word problems into mathematical models, which is the key factor in completing the given rich tasks correctly. Analysis of student responses exhibited that students who failed to develop the mathematical model were unable to solve rich tasks properly. This condition also corresponds with the teacher's reflection journal, which noted that students tended to confuse in generating ideas for modelling and they needed the teacher to reinforce the key concepts required by tasks. This students' problem in determining the mathematical model proved that their transformation skills were still lacking. This finding is relevant with previous studies conducted by Hadi et al. (2018), Jupri \& Drijvers (2016), Abdullah, Liyana, Abidin, \& Ali, (2017), Abdullah, Ibrahim, Surif, Ali, \& Hamzah (2015). They reported that the crucial constraint experienced by the students in solving mathematics HOTS items is in developing the mathematical model. To address this students' problem during the learning process, the teacher encourages students to identify the information from the task and think which mathematics concepts can be used to represent the condition and solve the problem.

Difficulty in mathematical process skills was found during this cyclic study when students were unable to perform and manipulated an algebraic form. This happened because their conceptual understanding was poor. Some students were unable to recall the previously taught mathematical concepts or principles. These research findings are in line with the results obtained by Hadi et al. (2018) and Alhassora et al. (2017), who found that one of the problems in solving HOTS test items is the lack of students' conceptual understanding.

Another difficulty experienced by students in solving the rich task is concerning encoding. It can be identified from students' work that they were unable to interpret the results. This is an indication that their reasoning skills remain low. To evaluate these conditions, the researchers made some revisions in the second cycle learning process, including revising the lesson plan and the student worksheet by adding more modelling tasks or mathematics items required process skills, as well as reasoning skill for student exercises.

One of the purposes of the action research study is to improve teaching practice (Creswell, 2009; Doğan \& Kilic 2020), in which a teacher or researcher is required to reflect on all the problems and conditions happened that could impede the learning objectives. The ability of the teacher to identify the problems and find the solution for those problems are a crucial component 
in conducted classroom action research successfully. One of the problems during rich task-based instruction that should be considered carefully is students' difficulties in solving rich tasks. Any revision made in each cycle should be based on these data. The learning process could be considered successful if the students are able to solve rich tasks correctly. Regarding this, many efforts have been implemented by the teacher during the learning cycle intervention to overcome those difficulties. For example, when students were unable to transfer the real-life condition into a mathematical model, the teacher encouraged students to highlight keywords and to illustrate the condition using picture/mathematics symbols and provided more activity related to modelling tasks in the student worksheet. Concerning student difficulty in processing mathematical skills, the teacher provided learning sources, such as textbooks, PowerPoint slides presentation/handouts. The teacher also directed students to utilize textbooks and previous mathematics lesson notes as a source of learning to help them recall prior learning materials, skills, and strategies used. Math activities related to process skills in the student worksheet as student exercises were also provided. Likewise, when students struggle in defining the conclusion of their findings, the teacher asked students to read their answers to the teacher, explain how they derived at their findings and asked them to relate the findings to the main question. The teacher also applied the Number Head Together (NHT) learning method to overcome the problem of students' less participation in group work. Through this strategy, every student in the group was assigned a number; then the teacher would randomly pick up the number to present their group works. This method required most low-ability students who are still facing difficulties to compensate with the other students to work in a group. This setting enables high-ability students in the group to help the other students, which in turn can lead to low-ability students to become confident in solving the task and in the presentation. Sumarni et al. (2016) said that the level of understanding and teaching management are the factors that can affect students 'attitudes toward learning. The data of students' responses have shown that the application of these solutions can enhance students HOTS at the end of the intervention cycle.

In the pre-cycle test, the students' HOTS scores were low because students submitted a blank answer sheet, indicating that they were unable to solve the rich task given. Moreover, the percentage of students who were in the low category was quite high in each cycle. This is an indication that students were still having difficulties in working on rich tasks, even though they got enough training and guidance during the intervention. It is proved that teaching HOTS for students is challenging (Jaelani \& Retnawati, 2016). The high percentage of students were in a low category because they did not answer the task correctly. This was evidence that they were not interested and challenged in solving the rich tasks. It happened because the students were not accustomed to HOTS mathematics items like rich tasks. Thus, the students were confused when solving the tasks. Retnawati, Hadi and Nugraha (2016) suggested frequent use of HOTS problems in assessment, while Hadi et al. (2018) argued that teacher needs to be trained properly to conduct effective HOTS based instruction. While King et al. (2011) recommended teachers to use a scaffolding (giving students support at the beginning of a lesson and gradually requiring students to operate independently) to helps students develop HOTS.

In the third cycle, the overall result showed an increase in students' HOTS. The improvement of the score is statistically significant (Table 3), indicating that utilizing rich tasks following problem-based learning can enhance students' HOTS. This finding is in accordance with Retnawati et al. (2017) and Fitriati and Novita (2018), which stated that the use of PBL could improve students HOTS especially their skills in problem-solving, including the ability to understand, to plan, to organize and to critically evaluate the results.

Based on the results of action research conducted, it can be concluded that the problembased learning model with rich tasks is essential and beneficial for the student to develop HOTS. Rich tasks allow students to understand the problem by examining the situation before identifying strategies for solution, exercises teamwork skills by collaborating with the team members, and presenting various problem-solving strategies. Rich tasks also enable students to use their knowledge for a novel context, linking mathematical concepts and use reasoning for peer-review. 
It is believed that this activity could train students to develop their HOTS. The results show that the problem-based learning model with the rich tasks has enhanced HOTS from the low category to the very good category; the mean score for each cycle is also improved. These showed that problem-based learning model with rich tasks effectively used to develop junior high school students' HOTS. This finding is also relevant with previous study conducted by Fitriati, Novita and Johar (2020) who found that rich tasks were able to improve students' reflective thinking, one of HOTS indicators.

Incorporating rich tasks in mathematics instruction has yielded findings of pedagogical importance. The use of rich tasks is able to train students to develop HOTS which is in lined with the 21st century demand. In addition, as the current PISA study has reported that mathematics literacy of Indonesian students are still weak, rich task is one of the solutions. Indonesian students must be habituated with solving rich tasks. Therefore, teacher are expected to carefully considered the kind of the tasks to be used in their teaching whether it has a significant impact on the expected students' thinking and other learning outcomes especially HOTS. Tambunan (2019) said that merely pick up materials from the package workbook is not enough for teachers. They need to find other resources to support their teaching practice. Moreover, they are required to enrich and broaden their knowledge and skills to be able to implement challenging conceptual tasks such as rich tasks in their classroom to assist students in developing their higher order thinking skills.

Regarding this, this study provides some recommendations for further research. The implementation of rich mathematical tasks in different and more complex cases to develop other aspects of higher order thinking skills are needed to reinforce the conclusion that this learning approach (problem-based learning with rich tasks) is applicable. In addition, this best practice of collaborative action research in enhancing student HOTS suggests that teachers need to be equipped with a professional development program on effective practice of rich tasks hoping they will gradually integrated rich tasks across school curricula and grade level.

\section{ACKNOWLEDGMENT}

We would like to thank the Directorate General of Higher Education, Ministry of Education and Culture of the Republic of Indonesia, and STKIP Bina Bangsa Getsempena, which has provided funding for this study.

\section{REFERENCES}

Abdullah, A. H., Ibrahim, N. H., Surif, J., Ali, M., \& Hamzah, M. H. (2014). "Non-routine mathematical problems among in-service and pre-service mathematics teachers". Paper presented at International Conference on Teaching, Assessment and Learning (TALE), Wellington: New Zealand.

Abdullah, A. H., Liyana, N., Abidin, Z., \& Ali, M. (2017). Analysis of Students ' Errors in Solving Higher Order Thinking Skills (HOTS ) Problems for the Topic of Fraction, 11(21), 133-142.

Alhassora, N.S.A., Abu, M.S., \& Abdullah, A. H. (2017). Inculcating higher-order thinking skill in mathematics: Why is it so hard? Man in India, 97(13), 51-62.

Aubusson, P., Burke, P., Schuck, S., Kearney, M., \& Frischknecht, B. (2014). Teachers Choosing Rich Tasks: The Moderating Impact of Technology on Student Learning, Enjoyment, and Preparation. Educational Researcher, 43(5), 219-229.

Brookhart, S. M. (2010). How to asses higher order thinking skills in your classroom. Alexandria, VA: ASCD.

Confrey, J., Gianopulos, G., McGowan, W., Shah, M., \& Belcher, M. (2017). Scaffolding learner-centered curricular coherence using learning maps and diagnostic assessments designed around mathematics learning trajectories. ZDM, 49(5), 717-734.

Corbin, J. M., \& Strauss, A. L. (2008). Basics of qualitative research: Techniques and procedures for developing grounded theory. Los Angeles, Calif.: Sage Publications, Inc.

Creswell, J.W. (2009). Educational research: Planning, conducting, and evaluating quantitative and qualitative research (1st ed.). Boston, MA: Pearson.

Darling-Harmond, L. (2012). Policy Frameworks for New Assessments. In P.Griffin et al. (eds). Assessment and Teaching of 21st Century Skills.

Doğan, O., \& Kilic, H. (2020). Learning and t eaching with p reservice t eachers : An action research for 
modelling and building faculty- school collaboration, Elementary Education Online. 19(1), 18-30.

Fergusson, S (2009). Same tasks, different paths: catering for students' diversity in mathematics classroom. $A P M C, 14(2), 32-36$.

Ferguson, S. (2009). Teachers ' Use of Mathematics Tasks : The Impact on the Mathematics Learning and Affective Responses of Low-attaining Upper Primary Students. Crossing Divides: Proceedings of the 32nd Annual Conference of the Mathematics Education Research Group of Australasia (Vol. 1), 1, 185-192.

Field, A. (2009). Discovering statistics using SPSS (3rd ed.). London: SAGE publications Ltd

Fitriati, F and Novita, R (2018). Designing student worksheet for rich mathematical tasks. Journal of Physics: Conference Series 0188012029.

Fitriati, F., Novita, R., and Johar, R. (2020). Exploring the usefullness of rich mathematical tasks to enhance students' reflective thinking, Cakrawala Pendidikan, 39 (2), 346-389.

Foster, C. (2017). Developing Mathematical Fluency: Comparing exercises and rich task. Educational Studies in Mathematics, 1-21.

Flewelling, G., and Higginson, W. (2002). Realizing a Vision of Tomorrow's Classroom, 5 May 2017 retrieved from http://math.unipa.it/ grim/AFlewelling70-72.PDF.

Glover, A (2016). Exploring Misconception with Rich Tasks. Ohio Journal of School Mathematics. 73. 43-49. 9 January 2018 retrieved from http://hdl.handle.net/1811/80137.

Goos, M., Geiger, V., dan Doley, S. (2013), “Designing Rich Numeracy Tasks”, in Proceedings of ICMI Study 22 Vol 1 on Task Design In Mathematics Education, Oxford, UK.

Gravemeijer, K., Stephan, M., Julie, C., Lin, F. L., \& Ohtani, M. (2017). What mathematics education may prepare students for the society of the future?. International Journal of Science and Mathematics Education, 15(1), 105-123.

Grootenboer, P. (2009). Rich Mathematical Tasks in the Maths in the Kimberley ( MITK ) Project, 1. In R. Hunter, B. Bicknell, \& T. Burgess (Eds.), Crossing divides: Proceedings of the 32nd annual conference of the Mathematics Education Research Group of Australasia (Vol. 1). Palmerston North, NZ: MERGA.

Hadar, L. L., \& Tirosh, M. (2019). Creative thinking in mathematics curriculum: An analytic framework. Thinking Skills and Creativity, 33, 100585.

Henningsen, M., \& Stein, M. K. (1997). Mathematical Tasks and Student Cognition: Classroom-Based Factors That Support and Inhibit High-Level Mathematical Thinking and Reasoning. Journal for Research in Mathematics Education, 28(5), 524.

Husamah, Fatmawati, D., \& Setyawan, D. (2018). OIDDE Learning Model : Improving Higher Order Thinking Skills of Biology Teacher Candidates, International Journal of Instruction. 11(2), 249-264.

Jaelani, J. \& Retnawati, H. (2016). The challenges of junior high school mathematics teachers in implementing the problem-based learning for improving the higher-order thinking skills. The Online Journal of Counseling and Education, 5 (3), 1-13.

Jailani, J., Sugiman, S., \& Apino, E. (2017). Implementing the problem-based learning in order to im- prove the students' HOTS and characters. Jurnal Riset Pendidikan Matematika, 4 (2), 247-259.

Jupri, A., \& Drijvers, P. (2016). Student Difficulties in Mathematizing Word Problems in Algebra, Eurasia Journal of Mathematics, Science \& Technology Education. 12(9), 2481-2502.

Kemmis, S., McTaggart., and Nixon, R. (2014). The action research planner: doing critical participatory action research. Singapore: Springer

King, FJ., Goodson, L., \& Rohani, F. (2011). Higher Order Thinking Skills • Definition • Teaching Strategies • Assessment. Educational Service Program. 20 August 2019 retrieved from https://informationtips.files.wordpress.com/2016/02/higher-order-thinking-skills_pdf.

Kwan, C. (2014). Student learning and engagement in Mathematics flipped classrooms : An action research study in a secondary school, 135-166.

Lingard, R. Ladwig, J., Mills, M., Bahr, M., Chant, D., Warry, M., et al. (2001). The Queensland school reform longitudinal study. Brisbane: Education Queensland.

Ministry of Education and Culture. (2013), Pergeseran Paradigma Belajar Abad 21, 20 March 2014 retrieved from http://kemdikbud.go.id/kemdikbud/uji-publik-kurikulum-2013-2.

Ministry of Education and Culture. (2018). Regulation of the Minister of Education and Culture of the Republic Indonesia Number 35 year 2018 on 2013 curriculum of secondary school

Ministry of Education and Culture. (2018). HOTS based instruction guide book for teachers: Program peningkatan kompetensi pembelajaran berbasis zonasi.

Moulds, P. (2002). Rich tasks : Developing student learning around important tasks. Australian Science Teachers Journal, 48(4), 6-13.

Moulds, P. (2004). Rich Tasks. Educational Leaderships, 51 (4), 75-78. 
NRICH. (2019). Mathematics resources for teachers, parents and students to enrich learning. $10 \mathrm{March}$ 2019 retrieved from https://nrich.maths.org/.

Nurlaily, V. A., Soegiyanto, H., \& Usodo, B. (2019). Elementary school teacher's obstacles in the implementation of problem-based learnıng model in mathematics learning, Journal on Mathematics Education. 10(2), 229-238.

OECD (2012). PISA Results: What student know and can do-students performance in reading, mathematics $\begin{array}{llllll}\text { and science } & \text { (Volume } & \text { 1). } 5 & \text { March } 2016 & \text { retrieved from }\end{array}$ http://dx.doi.org/10.178/9789264091450.en.

OECD. (2018a). PISA Result in Focus. 18 April 2019 retrieved from https://www.oecd.org/pisa/pisa-2015results-infocus.pdf.

Pak, K., Polikoff, M. S., Desimone, L. M., \& Saldívar García, E. (2020). The Adaptive Challenges of Curriculum Implementation: Insights for Educational Leaders Driving Standards-Based Reform. AERA Open, 6(2), 2332858420932828.

Piggott, J (2012), Rich Task and Contexts, 6 June 2014 retrieved from http://nrich.maths.org/5662.

Polya, G. (1973). How to solve it: A new aspect of mathematical method. Princeton, N. J.: Princeton University Press.

Pratiwi, I. (2019). PISA effect on curriculum in Indonesia. Jurnal Pendidikan dan Kebudayaan. 4(1). 51-71.

Raymond, A. M., \& Leinenbach, M. (2000). Collaborative action research on the learning ang teaching of algebra: a story of one mathematics teacher's development. Educational Studies in Mathematics, 41, 283 -307.

Retnawati, H., Djidu, H., Apino, E., \& Anazifa, R. D. (2017). Teachers' knowledge about higher-order thinking skills and its learning strategy. Problems of Education in the 21st Century, 75 (2), 215-230.

Retnawati, H., Hadi, S., \& Nugraha, A. C. (2016). Vocational high school teachers' difficulties in implementing the assessment in curriculum 2013 in Yogyakarta Province of Indonesia. International Journal of Instruction, 9 (1), 33-48.

Stacey, K. (2011). The view of mathematics literacy in Indonesia. Journal on Mathematics Education (Indo$\left.M S \_J M E\right), 2(1), 1-24$.

Sumarni, W., Wardani, S., Sudarmin., Gupitasari, D. N (2016), Project Based Learning to improve phycomotoric skills: A Classroom action research. Jurnal Pendidikan IPA Indonesia. 5 (2), 157-163.

Slavit, D., \& Nelson, T. H. (2010). Collaborative teacher inquiry as a tool for building theory on the development and use of rich mathematical tasks. Journal of Mathematics Teacher Education, 13(3), 201-221.

Tambunan, H. (2019). The effectiveness of problem solving strategy and the scientific approach to student capabilities in higher order thinking skill. International Electronic Journal of Mathematics Education. 14(2). 293-302.

Tanujaya, B., Prahmana, R. C. I., \& Mumu, J. (2017). Mathematics instruction, problems, challenges and opportunities : a case study in Manokwari Regency, Indonesia, International Education Studies. 10(11), 78-85.

Udi, E.A, Clacke, D dan Kuntze, S (2013), "Hybrid Tasks: Promoting statistical thingking and critical thingking through the same mathematical activities". In Proceedings of ICMI Study 22 Vol 1 on Task Design In Mathematics Education, Oxford, UK. 